\title{
Aplikasi Pembelajaran Bahasa Indonesia Berbasis Android Pada Sekolah Menengah Pertama
}

\author{
Yulanda Yunus ${ }^{1}$ \\ ${ }^{1}$ e-mail: yulandayunus@gmail.com \\ ${ }^{1}$ Sistem informasi, STMIK Ichsan Gorontalo
}

\begin{abstract}
Lack of interest and attention of students of SMP Negeri 2 Suwawa in the learning process, because the effect of cell phone use that is generally used by students only to meet the lifestyle (gaming, social media). Parties SMP Negeri 2 Suwawa expects to combine the technology and education so that students not only use mobile phones or mobile phones to meet the lifestyle can be used for media / means of learning, so that students not only learn in the classroom, but can be done anywhere and anytime, especially Indonesian subjects for these subjects is one of three subjects were used as subjects in the National Examination both at the level of secondary school (SMP). Learning applications Indonesian Based Android is expected to attract renewed interest in learning Indonesian students and help students to more easily learn and understand the lesson Indonesian. This application is built using Eclipse Juno software, SQLite, and implemented in the Android mobile operating system is growing rapidly. , Based on the results pengujiaan whitebox on one of the processes in this system that is on the menu with the acquisition of material balanced result $V(G)=5$ and Ciclometic Complexity $(C C)=5$, then the system is declared to run well. While the test results Blacbox system can run as expected.
\end{abstract}

Keywords - Indonesian, Android, Learning, School.

Abstrak - Kurangnya minat dan perhatian siswa SMP Negeri 2 Suwawa dalam proses belajar mengajar, karena pengaruh penggunaan telepon seluler yang umumnya digunakan siswa hanya untuk memenuhi gaya hidup (main game, sosial media). Pihak SMP Negeri 2 Suwawa mengharapkan dapat mengkombinasikan antara teknologi dan pendidikan sehingga siswa tidak hanya menggunakan handphone atau telepon seluler untuk memenuhi gaya hidup dapat dimanfaatkan untuk media/sarana belajar, sehingga siswa tidak hanya belajar di dalam kelas namun bisa dilakukan dimana saja dan kapan saja khususnya mata pelajaran Bahasa Indonesia karena mata pelajaran tersebut merupakan satu dari tiga mata pelajaran yang dijadikan sebagai mata pelajaran dalam Ujian Nasional baik di tingkat Sekolah Menengah Pertama (SMP). Aplikasi Pembelajaran Bahasa Indonesia Berbasis Android diharapkan dapat menarik kembali minat siswa dalam belajar Bahasa Indonesia dan membantu siswa untuk lebih mudah belajar dan memahami pelajaran Bahasa Indonesia. Aplikasi ini dibangun dengan menggunakan software Eclipse Juno, SQLite, dan diimplementasikan dalam sistem oprasi mobile yaitu Android yang sedang berkembang pesat. . Berdasarkan hasil pengujiaan Whitebox pada salah satu proses dalam sistem ini yaitu pada menu materi dengan perolehan hasil yang seimbang $\mathrm{V}(\mathrm{G})=5$ dan Ciclometic Complexity $(C C)=5$, maka sistem ini dinyatakan dapat berjalan dengan baik. Sedangkan hasil pengujian Blacbox sistem dapat berjalan sesuai dengan yang diharapkan.

Kata Kunci-Bahasa Indonesia, Android, Pembelajaran, Sekolah. 


\section{PENDAHULUAN}

Sekolah adalah lembaga pendidikan formal yang dirancang khusus untuk pengajaran para murid (siswa) di bawah pengawasan para guru (Permendikbud, No.3). Sekolah yang pada dasarnya sebagai sarana untuk melaksanakan pendidikan memang diharapkan bisa menjadikan masyarakat yang lebih maju, oleh sebab itu sekolah sebagai pusat dari pendidikan harus bisa melaksanakan fungsinya dengan optimal dan perannya bisa menyiapkan para generasi muda sebelum mereka terjun di dalam proses pembangunan masyarakat.

Sekolah menawarkan pendidikan formal melalui jenjang pendidikan. Menurut Permendikbud No.3 Tahun 2013 yang merujuk pada UU No.20 Tahun 2003 tentang Sisdiknas (Permendikbud, No.3). Jenjang pendidikan adalah tahapan pendidikan yang ditetapkan berdasarkan tingkat perkembangan peserta didik, tujuan yang akan dicapai, dan kemampuan yang dikembangkan. Jenjang pendidikan formal di Indonesia terdiri dari Sekolah Dasar (SD), Sekolah Menengah Pertama (SMP), Sekolah Menengah Atas (SMA), dan Pendidikan Tinggi.

Sekolah Menengah Pertama merupakan jenjang pendidikan dasar pada pendidikan formal di Indonesia yang ditempuh dalam waktu 3 tahun. Pelajar sekolah atau siswa menengah pertama umumnya berusia 13-15 tahun. Sekolah Menengah Pertama merupakan masa transisi dari masa kanak-kanak ke dunia remaja. Masa SMP merupakan masa yang kritis bagi pendidikan siswa karena pada masa ini merupakan masa transisi dari kanak-kanak (www.kemendiknas.co.id). Saat ini pendidikan Siswa SMP sangat dipengaruhi oleh perkembangan teknologi yang menyediakan berbagai macam kemudahan sehingga mempengaruhi pemikiran siswa, sehingga sekolah harus mulai bekerja keras dan memberi perhatian terhadap program dan metode pendidikan yang digunakan dalam mentransfer ilmu pengetahuan dari tenaga pengajar kepada siswa.

Awalanya perkembangan teknologi di bidang pendidikan ditandai dengan lahirnya konsep Elekronik Learning (e-learning) dimana semua bentuk pengajaran dan pembelajaran menggunakan rangkaian elektronik berupa CD audio, video interaktif, LAN, WAN atau internet untuk menyampaikan isi pembelajaran, interaksi dan bimbingan (Jurnal Teknologi Informasi dan Komunikasi). Penggunaan rangkaian elektonik tersebut memungkinkan pembelajaran dapat dilakukan dalam waktu yang sama atau berbeda. Pembelajaran juga dapat dilakukan dalam satu tempat atau beda tempat melalui pembelajaran jarak jauh.

Meskipun e-learning dapat dilaksanakan kapan saja dan dimana saja, namun e-learning masih memiliki kekurangan yaitu mengharuskan penggunanya untuk berhadapan dengan peralatan elektronik yang tidak fleksibel untuk berpindah tempat (contoh personal computer (PC)), DVD player, TV) yang terhubung ke internet menggunakan kabel LAN (Nugraha, 2016). Siswa secara tidak langsung tetap dibatasi oleh tempat dan fasilitas tertentu oleh karena itu e-learning belum sepenuhnya dapat menjadi solusi agar siswa dapat belajar kapan saja dan dimana saja tanpa dibatasi oleh waktu dan tempat dengan mudah dan terjangkau.

Menanggapi permasalahan tersebut kemudian dikembangkan media pembelajaran baru dengan memanfaatkan media genggam atau bergerak (mobile) yang dapat digunakan kapan saja, dimana saja dan hampir semua kalangan masyarakat pada saat ini dapat mengoperasikannya (Maulana, 2015). Salah satu perangkat bergerak atau mobile yang keberadaannya tidak dapat lepas dari kehidupan sehari-hari adalah telepon genggam atau yang lebih dikenal dengan handphone.

Telepon genggam saat ini tidak hanya digunakan sebagai alat komunikasi tetapi dapat digunakan dalam mencari informasi. Salah satu sistem operasi saat ini yang dapat mengakses informasi dengan sangat cepat dan paling banyak diminati oleh masyarakat saat ini adalah android. Android merupakan sistem yang berbasis open source yang memungkinkan sources code (kode sumber) pada android dapat dibaca oleh pengembang untuk mengkostumisasi berbagai fitur aplikasi sesuai dengan kebutuhan penggunannya (Hanif, 2015).

Perkembangan telepon seluler kemudian dimanfaatkan dalam dunia pendidikan yang menjanjikan indepensi waktu dan lebih dikenal dengan istilah mobile learning (m-learning). Menurut Yunita, 2017, Perangkat mobile yang digunakan dalam mobile learning antara lain Personal Digital Assistant (PDA), handphone, laptop atau tablet PC. Karateristik perangkat mobile ini memiliki tingkat fleksibilitas dan portabilitas yang tinggi sehingga memungkinkan siswa dapat mengakses materi, arahan dan informasi yang berkaitan dengan pembelajaran kapanpun dan dimanapun sehingga meningkatkan perhatian siswa pada materi pembelajaran.

Aplikasi dalam bentuk mobile merupakan solusi yang dapat menjawab kekurangan dari sistem pembelajaran yang telah ada. Aplikasi ini mempunyai beberapa kelebihan diantaranya sebagai media edutaiment, suatu media yang menggabungkan unsur edukasi (education) dan hiburan (entertainment) atau belajar sambil bermain, serta mudah untuk dibawa kemana-mana (Yunita, 2017).

Mobile learning dapat dijadikan sebagai salah satu alternatif untuk memecahkan permasalahan dalam bidang pendidikan, terutama masalah pemerataan akses informasi pendidikan, kualitas konten pembelajaran yang berupa materi pembelajaran dalam bentuk teks ataupun gambar disertai dengan contoh-contoh soal serta peningkatan kualitas pengajar agar lebih baik dalam membuat atau menyampaikan materi pembelajaran dan mengelola kegiatan belajar mengajar (Yunita, 2017).

Dari observasi awal di SMP Negeri 2 Suwawa hampir semua siswa telah menggunakan telepon seluler/handphone yang saat ini lebih dikenal dengan "Smartphone". Rata-rata dari siswa tersebut menggunakan smartphone hanya untuk kebutuhan memenuhi gaya hidup (bermain game, dan sosial media), sehingga minat dan perhatian siswa pada materi pelajaran di saat proses belajar mengajar berkurang, mereka hanya fokus pada smartphone yang menurut mereka lebih menyediakan informasi lebih luas.

Hal ini merupakan masalah dan tantangan bagi pihak sekolah (SMP Negeri 2 Suwawa) untuk bagaimana mampu menciptakan metode belajar yang diminati siswa sehingga menarik kembali perhatian dan fokus siswa pada materi pembelajaran yang diharapkan. Pihak sekolah SMP Negeri 2 Suwawa mengharapkan dapat mengkombinasikan antara teknologi 
dan pendidikan sehingga siswa tidak hanya menggunakan handphone atau telepon seluler untuk memenuhi gaya hidup (main game, sosial media), namun bisa dimanfaatkan untuk media/sarana belajar, jadi siswa tidak hanya belajar di dalam kelas namun bisa dilakukan dimana saja dan kapan saja. Saat ini penetapan standar pendidikan semakin tinggi, untuk bisa lulus dari SMP siswa harus mengikuti Ujian Nasional. Adapun mata pelajaran Ujian Nasional yang ditetapkan untuk memenuhi syarat kelulusan siswa SMP antara lain: Bahasa Indonesia, Matematika, dan Bahasa Inggris, sehingga pihak sekolah dituntut agar mencari cara yang paling efektif dalam mentransfer ilmu secara cepat dan mudah.

Berdasarkan latar belakang tersebut, peneliti kemudian tertarik untuk membuat suatu aplikasi berbasis android sebagai media pembelajaran khusus pada mata pelajaran Bahasa Indonesia karena mata pelajaran tersebut merupakan satu dari tiga mata pelajaran yang dijadikan sebagai mata pelajaran dalam Ujian Nasional baik di tingkat Sekolah Menengah Pertama (SMP) ataupun Sekolah Menengah Atas (SMA).

Ketertarikan akan media pembelajaran tersebut kemudian dituangkan oleh penulis di dalam skripsi yang berjudul : "Aplikasi Pembelajaran Bahasa Indonesia Berbasis Android Pada Sekolah Menengah Pertama (SMP) 2 Suwawa".

\section{TUJUAN PENELITIAN}

Tujuan dalam penelitian ini adalah:

Berdasarkan rumusan masalah tersebut, maka tujuan dari penelitian ini yaitu merancang dan merealisasikan aplikasi pembelajaran bahasa Indonesia berbasis android untuk mendukung kegiatan belajar mengajar serta menarik perhatian dan fokus siswa pada materi pembelajaran bahasa Indonesia yang diajarkan.

\section{METODE PENELITIAN}

\section{Metode Penelitian}

Dalam melakukan suatu penelitian perlu dilakukan perencanaan penelitian agar penelitian yang dilakukan dapat berjalan dengan baik dan sistematis. Pada penelitian ini penulis mencoba memadukan antara metode penelitian Deskriptif dan penelitian Tindakan. Penelitian Deskriptif adalah suatu metode dalam meneliti status sekelompok manusia, suatu objek, suatu set kondisi, suatu sistem pemikiran, ataupun suatu kelas peristiwa pada masa sekarang. Tujuan dari penelitian deskriptif ini adalah untuk menjelaskan aspek-aspek yang relevan tentang fenomena perseorangan, organisasi, perusahaan berorientasi industri atau perspektif lainnya, membuat deskripsi, gambaran atau lukisan secara sistematis, faktual dan akurat mengenai faktafakta, sifat-sifat serta hubungan antara fenomena yang diselidiki (Saepul, 2016).

Sementara itu, Penelitian Tindakan bertujuan untuk mengembangkan keterampilan baru untuk mengatasi kebutuhan dalam dunia kerja atau kebutuhan praktis lain. Penelitian ini dikhususkan pada kebutuhan praktis yang berkaitan dengan dunia kerja, pengamatan secara aktual dan data tingkah laku dalam menyiapkan suatu program untuk pemecahan masalah, bersifat fleksibel atau dapat dilakukan perubahan selama proses penelitian bila dianggap penting untuk pembaruan (inovasi) (Saepul, 2016). Dengan kata lain, Penelitian tindakan bertujuan mengembangkan keterampilan-keterampilan baru atau cara pendekatan baru dan untuk memecahkan masalah dengan penerapan langsung di dunia kerja atau dunia aktual yang lain

Oleh karena itu, penulis berusaha mengkombinasikan antara dua penelitian ini dengan mengumpulkan masalah fakta-fakta aktual dan akurat terkait permasalahan yang dihadapi dan mencoba memecahkannya dengan pendekatan baru dengan membuat suatu program untuk dapat diterapkan langsung di dunia kerja.

\section{Teknik Pengumpulan Data}

Untuk mendapatkan data yang benar - benar akurat, relevan, valid dan dapat dipercaya maka pengumpulan data dilakukan sebagai berikut:

a. Observasi

Pengamatan dilakukan Sekolah Menengah Pertama (SMP) Negeri Suwawa.

b. Interview

Pengumpulan data dengan cara tatap muka dan tanya jawab langsung dengan sumber data yaitu Sekolah Menengah Pertama (SMP) 2 Suwawa.

C. Survei, Pengumpulan data dengan melakukan survey di Sekolah Menengah Pertama (SMP) 2 Suwawa

Studi pustaka, Pengumpulan data dengan cara membaca serta mempelajari dokumen-dokumen, literatur, buku, jurnal, video / gambar yang berhubungan dengan obyek penelitian. 


\section{ANALISIS DAN DESAIN SISTEM}

\section{Analisa Sistem yang diusulkan}

Sistem yang diusulkan digambarkan dengan usecase diagram di bawah ini.

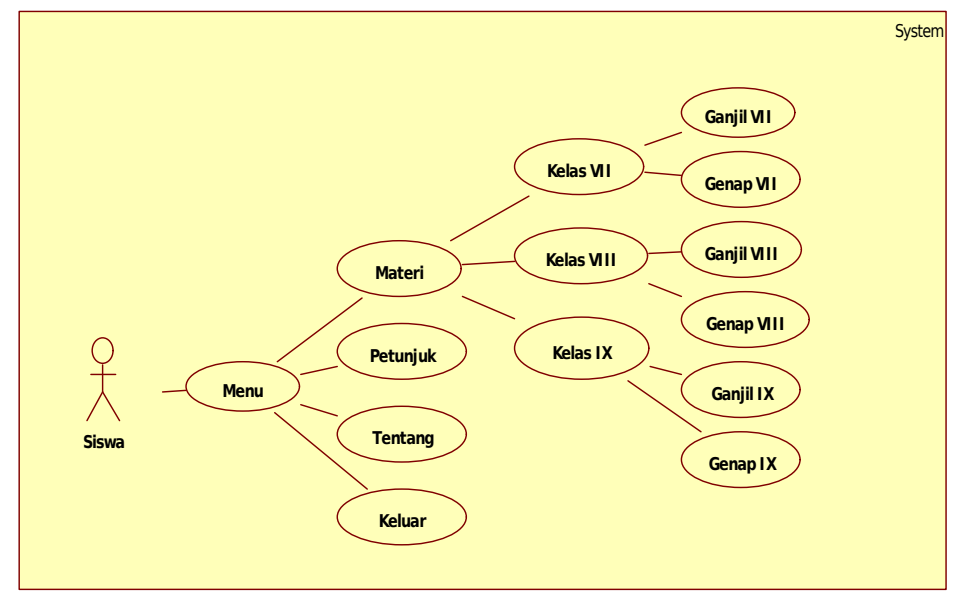

Gambar 4.1 Sistem yang diusulkan

Pada saat user masuk program, maka user akan menuju ke menu utama dari program yang terdiri dari : Materi, Petunjuk, Tentang, Keluar. User dapat mengakses materi untuk kelas VII, kelas VIX, dan kelas IX, dengan masing-masing kelas terbagi atas dua semester yakni semester ganjil dan semester genap.

\section{Tampilan Aplikasi}

Tampilan sistem pada server rancang sangat sederhana, sedangkan tampilan sistem yang berjalan di client dirancangan dengan mengoptimalkan kemudahan pengguna. Berikut merupakan tampilan Graphic User Interface dari sistem yang diusulkan :

\section{Halaman Splash Screen}

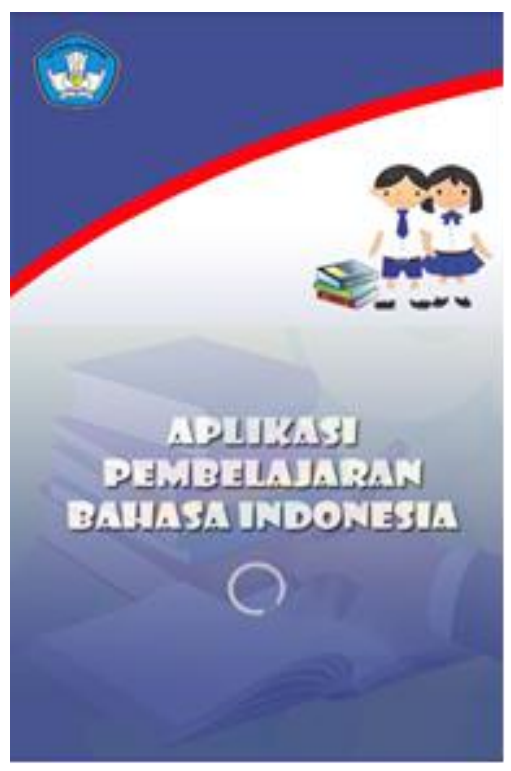


Gambar diatas merupakan tampilan splash Screen dari aplikasi.

Halaman Menu Utama

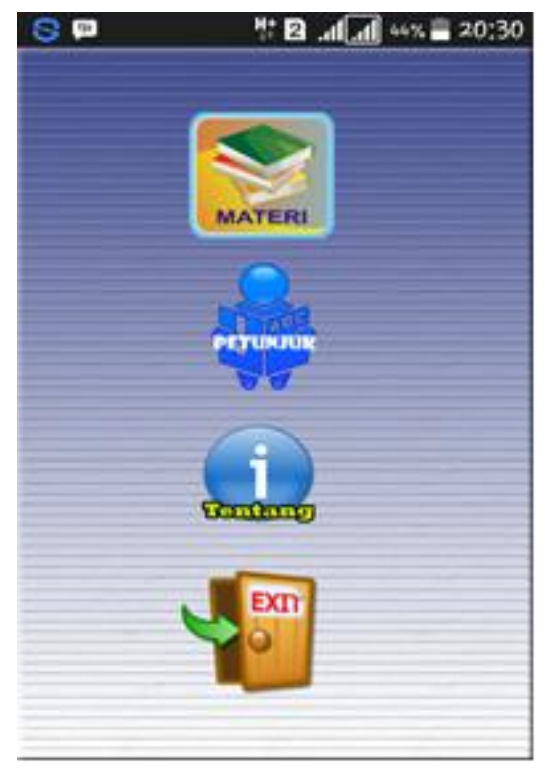

Gambar 4.3 Halaman Menu Utama

Menu utama adalah tampilan pertama aplikasi setelah splash screen. Pada tampilan menu utama ini terdiri dari empat icon pilihan tombol yaitu materi, petunjuk, tentang, dan keluar.

Halaman Pilih Kelas

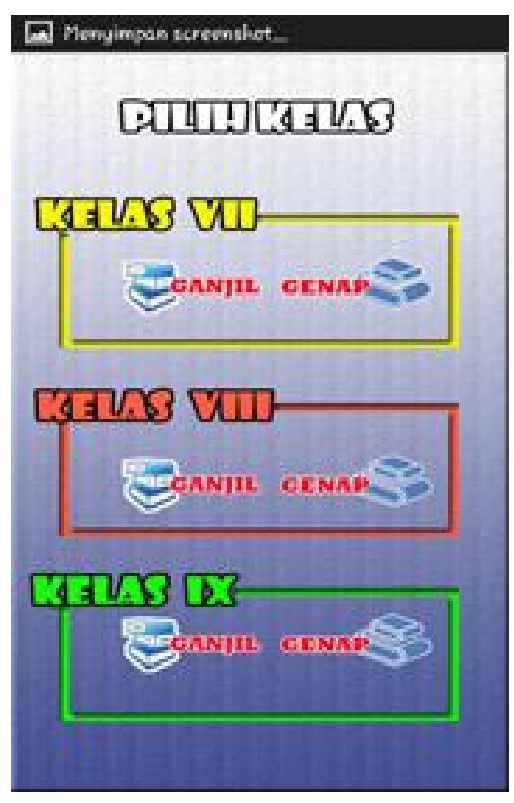

Gambar 4.4 Pilih Kelas 
Pada saat memilih icon materi, maka yang akan tampil adalah sub menu pilih kelas VII,VIII, dan IX yang terdiri dari dua pilihan semester ganjil dan genap

\section{Implementasi Sistem}

Implementasi merupakan suatu penerapan perancangan yang telah dilakukan terhadap sistem sehingga user dapat memberi masukan demi berkembangnya sistem yang telah dibangun sebagai simulasi dari penerapan Aplikasi Pembelajaran Bahasa Indonesia Berbasis Android.

\section{KESIMPULAN}

Penelitian ini menyimpulkan bahwa Hasil Pengujian aplikasi Pembelajaran Bahasa Indonesia Berbasis Android Pada Sekolah Menengah Pertama dengan menampilkan tampilan sesuai dan valid sehingga aplikasi dapat digunakan dengan cepat dan tepat.

\section{SARAN}

Penelitian ini masih terdapat kekurangan dan perlu diadakan pengembangan dalam rangka membuat sistem ini menjadi lebih baik yaitu aplikasi ini dapat dirancang dan dikembangkan lebih lanjut dalam fitur smartphone yang lebih bagus dan menarik agar sistem yang dibuat dapat dipakai user secara cepat dan tepat.

\section{REFERENSI}

[1] Efendi, Y. (2018). Rancangan Aplikasi Game Edukasi Berbasis Mobile Menggunakan App Inventor. Jurnal Intra-Tech, 39-48.

[2] Masruri Hilmi M.. 2015. Buku Pintar Android (Jurus Jitu Oprek Sendiri Smartphone anda)

[3] Satyaputra, Alfa \& Maulina Eva Aritonang. (2016). Let's Build Your Android Apps With Android Studio. Jakarta : PT Elex Media Komputindo

[4] Safaat H, Nazruddin, 2015. Android Pemrograman Aplikasi Mobile Smartphone dan Tablet PC berbasis Android (edisi re Informatika; Bandung.

[5] Widhoasih, d. (2016). Pengembangan media pembelajaran mlearning berbasis android pada mata pelajaran sistem komputer di smk negeri 3 surabaya. Jurnal it-edu, pp. 58-64. 